\title{
Protest camps: an emerging field of social movement research ${ }^{1}$
}

\author{
By Fabian Frenzel, Anna Feigenbaum and Patrick McCurdy
}

\section{Citation}

Frenzel, F., Feigenbaum, A., and McCurdy, P., " Protest camps: an emerging field of social movement research ", Sociological Review, January 2014.

\begin{abstract}
Recently protest camps have emerged around the world as a highly visible form of protest. Part and parcel of European new social movement activism for the last 30 years, they are important sites and catalysts for identity creation, expression, political contention and incubators for social change. While research has punctually addressed individual camps, there is lack of comparative and comprehensive research that links historic and contemporary protest camps as a unique area of interdisciplinary study. Research on the phenomenon to date has remained punctual and case based. This paper contributes a theoretical framework for a comprehensive study of the phenomenon. Existing literature is critically reviewed and framed in three thematic clusters of spatiality, affect and autonomy. On the basis of this review the paper develops a research approach based on the analysis of infrastructures used to make protest camps. We contest that an infrastructural analysis highlights protest camps as a unique organisational form and transcends the limits of case-based research while respecting the varying contexts and trajectories of protest camps.
\end{abstract}

\section{Introduction}

From Tahrir Square to Syntagma Square, from the Puerto del Sol to the streets of Tel Aviv, from Wall Street to the London Stock Exchange, protest camps are a global phenomenon. They occur across a wide range of social movements and encompass a diversity of demands for social change. They are spaces where people come together to imagine alternative worlds and articulate contentious politics, often in confrontation with the state. Yet, despite protest camps

\footnotetext{
${ }^{1}$ We would like to thank Stephen Dunne and our three anonymous reviewers for their insightful comments on the manuscript of this paper.
} 
increasing role as an organisational form of protest, research on camps is limited. What research exists is sporadic and dotted across a range of disciplines from social movement studies, media and communication studies to political science and organisation studies. Most of this existing scholarship regards camps as just one form of protest among many. They are grouped together with other strategies such as street parties, demonstrations, assemblies and direct actions and often discussed within the confines of a single movement (Epstein 2002; McKay 1998; Pickerill and Chatterton 2006; Crossley 2003; Chesters and Welch 2004). Yet as recent world events reveal, protest camps are not just a passing tactic. They can be the focal point of a movement both organisationally and symbolically. The dramatic rise in the political significance and visibility of protest camping witnessed since early 2011 demands a more focused analysis of the protest camp as both a contemporary and an historical movement practice. In this article we employ cross-disciplinary research on social movements to develop a new approach that recognises protest camps as a unique sociological phenomenon and enables the comparative study of protest camps. Through building this approach, we have two interrelated goals. First, to recognise protest camps as unique sites of sociological interest and relevance. Second, and related, to encourage further protest camp scholarship across movements and locations; to link historic and contemporary protest camps, and comparatively examine the structural similarities and differences between protest camps, and to map and understand their multiple, and often overlapping forms, contexts and trajectories. Our contribution is both an effort to synthesize past work, and an intervention into Final, accepted version. To be published in Sociological Review 
the multiple readings of the Occupy Movement as a phenomenon disconnected from the history of protest camping with the aim to push forward the agenda of protest camp research. This article, then, contributes to the creation of a muchneeded more comprehensive account of the historical and political significance of protest camps in order to better understand, and raise questions regarding the recent uptake of this form of political protest on a mass scale as seen in global events of 2011.

We start by reviewing literature on social movements in three conceptual clusters relevant to the study of protest camps: spatiality, affect and autonomy. There are overlaps between these three clusters and they cannot be understood as mutually exclusive. We identify key features of protest camps that emerge from the literature in each cluster. In spatiality this concerns the different roles space and place play for the understanding and possible interpretation of protest camps. This includes the notions of 'contested space', representational space, home space and convergence space.

In discussing affect we discuss how social movement theorists have recently placed emphasis on the roles of emotion in political protest. We draw from a range of the vast, cross-disciplinary perspectives on affect to discuss the concept in relation to 'transformative encounters' or 'bodily alterations' and 'transmissions of affect'. We argue that affect is key to how we understand 'conflict and collaboration' in the intimate and emotionally rich space of the protest camp. Regarding autonomy, key features are bio politics, affinity, non-representation and exceptionality. 
Thinking through the development of the debates we have clustered under the concepts of spatiality, affect and autonomy, leads us to propose our research approach which is based on analysing protest camp infrastructures. To do so we borrow from and apply analyses developed in debates around Actor Network Theory. We chose this approach because it converges with the practical, hands on, and DIY perspective protest campers prefer when they do politics in and with the camp. We also chose it because it helps us to overcome limits in previous literature on camps, particularly in regard to their lack of focus on the significance of the materiality of the camps in movement formation. Thus the infrastructural approach enables us to operationalize the literature derived from the conceptual clusters for a comparative analysis of empirical findings from a variety of protest camps.

Through this approach we can establish a set of material criteria and general modes of operation shared between camps. We identify and term these: domestic, action, communication and governance infrastructures. These categories are then formulated in relation to our three thematic clusters which open a matrix to code data from a variety of divergent camps for comparison and discussion. This approach facilitates the identification and investigation of differences between diverse samples of protest camps. We designed our approach in relation to Weber's model for understanding 'why particular features [are] present or absent in particular situations' (Greenwood and Levin 2007:70). It is not our objective to develop a structuralist or universalist account of protest camps, and we do not intend to limit future research on protest camps by prescribing a definite approach. Final, accepted version. To be published in Sociological Review 
Rather, given that there is currently no comprehensive scholarship on protest camps, our aim is to develop a set of common conceptual tools and a mode of analysis that can be used to better understand the increasingly popular phenomenon of protest camping, while remaining conscious and critical of contextual specificity.

Spatiality

Spatiality, in its various material and representation forms is at the heart of all protest camps. Discussions about the concept of space have proliferated in both academic and activist discourse captured in concepts such as 'temporary autonomous zones' (Bey 2003), 'convergence spaces' (Routledge 2000) and 'convergence centers' (Juris 2008), urban social centres (Montagna 2007, Hodkinson \& Chatterton 2007, Leontidou 2007) and in respect of student activism as 'campus connections' (Crossley 2008). The place of protest matters (Heaney and Roja 2006), and in the case of protest camps this fact is amplified. Protest camps are often defined by their physical location. The selection of a site for a protest camp is important for how the camp and its occupiers are framed by the media and perceived by the public. The symbolic value of the site, alongside its legal or proprietary status, affects how state authorities, police and local communities will react. Protest camps may be built upon contested physical areas, such as the proposed site for building a new road or oil pipeline. In such cases, the presence of the protest camp is a physical and direct intervention on a site which is perceived by those camping as at risk; at risk from takeover, demolition, 
destruction or eviction. The act of camping on site physically prevents, if only temporarily, the contentious action from happening. This type of protest camp commonly sees protesters occupying trees set for clearing, as with the Newbury Bypass and Minehaha Free State anti-roads camps.

Other protest camps directly target sites, which are seen as threats. This was the case, for example, with Greenham Common, where protesters camped out around the perimeter of a military base selected to store nuclear cruise missiles. Other peace camps, spread across four continents, followed suit with camps established outside of military bases and weapons manufacturing plants.

The symbolic element of protest campsites often attempts to draw attention to issues which are otherwise hard to concretise either because the issues are hard to make visible such as the global system of consumer capitalism, or target audiences which are otherwise disconnected from the issue at hand. From this perspective and drawing explicitly on Gamson and Wolfsfeld (1993), the symbolic role of protest camp can serve to mobilize protest campers, validate their cause and/or enlarge the scope of the issue at hand. Conscious of the symbolic element and its public and representational resonance protesters may select sites which are believed to embody the issues at hand or where the protest camp may attain visibility. For example, both the 2011 Occupy Wall Street camp at Zuccotti Park in New York City and the Occupy London Camp (Occupy LSX) erected on the steps of Saint Paul's Cathedral selected sites for their proximity to the financial centres. Given that the Occupy Wall Street movement had a broad focus on inequalities caused by the financial crisis, austerity measures and the state of hyper consumer Final, accepted version. To be published in Sociological Review 
capitalism, situating protest camps in close proximity to financial districts provides a physical and symbolic challenge to business as usual. In this sense protest camps form 'contested spaces'. There is also a long history of protest camps being established in close proximity to the large international gatherings of global elites such as WTO, G8, G20, FTAA and similar meetings (Frenzel 2010; McCurdy 2008, 2009). The protest camps, often called 'counter-summits,' not only served as bases for protests against these meetings, but were protests in themselves offering a visual challenge and counter-narrative to these heavily mediated events. Meanwhile the 1968 Resurrection City protest camp strategically picked its location on the Mall in Washington D.C. so that it would be in full view of both the seat of American power and the Whistehouse press corps therefore acting as both a visceral and symbolic reminder of the everyday struggles faced by Americans living in poverty.

Some protest camps have attempted to develop more 'permanent' organizational structures. The climate camp movement in the UK, for example, existed both in the form of actual protest camps and as an organisational framework that links campers and supporters with more regular gathering and exchanges including national organising meetings and large social media networks. The actual camps here arguably become a particular form of mobilization of a movement that exists beyond the camp with the benefit of a enabling a longer lasting strategy. After the discontinuation of its annual camp in the UK in 2010, Climate Camp, as a movement, continues with a 'New Directions' project in the UK working to 'reimage radical climate action' (Climate Camp 2011:1) and with a new camp in Final, accepted version. To be published in Sociological Review 
summer 2013. Climate Camps also continue to run in North America, Europe and Australia. For us this highlights yet a different notion of spatiality that relates to the protest camp. Although rarely discussed protest camps are also representational spaces, standing for movements and positions. They come to signify a focal point for both external and internal identification.

Whether protest camps last for an afternoon or a decade, they become places where people and ideas converge. As briefly discussed above, the concepts of the 'convergence space' and 'convergence centre' have received academic and activist attention as both a physical and conceptual meeting point. Routledge (2000) has developed the idea of the 'convergence space' to refer to the conceptual arena where networks can align themselves and organise under. Convergence spaces are defined by Routledge as:

Common ground between various social movements, grassroots initiatives, non-governmental organisations and other formations, wherein certain interests, goals, tactics and strategies converge. It is a space of facilitation, solidarity, communication, coordination, and information sharing. It is both virtual - enacted through the internet - and material, enacted through conferences and various kinds of direct action such as demonstrations and strikes (Routledge 2000:35).

Convergence spaces take a material form when they manifest in a physical location where different groups and people come together. Protest camps may be seen as the materialisation of Routledge's 'convergence spaces'.

The physicality of such sites is often discussed via the notion of 'convergence centres' (Juris 2008:172-173; Routledge 2003). The term 'convergence centre' has been commonly used by activists to refer to 'immediate' or physical locations 
that offer a common focal point for activists to assemble, discuss, strategise and share skills, knowledge and experience. Such spaces can also act as strategic locations from which activists can plan and execute protest actions. In respect of student activism, Crossley (2008) has shown the importance of physical connectivity 'on campus' in explaining the politicization of students. Juris (2008), building on hooks (1990) refers to the convergence centre as a 'home place' and describes convergence centres as 'small, self-managed city, a 'heterotopic space' of exchange and innovation' (Juris, 2008, p. 129). This aspect of building a 'home place' is something, which differentiates the protest camp from other place-based or space-based social movement gatherings. Here protest camps relate historically to intentional communities, for example the formations of 19th century radicalism and utopian socialism that set up socialist communities to prefigure a socialist society (Brown 2002, Schehr 1997). Indeed protest camps are well placed in this historic tradition and the study of continuities and discontinuities between intentional communities and protest camps - in particular those that last for longer periods of time - is lacking.

Perhaps in difference to many intentional communities that are set up in stable dwellings, at protest camps activists often forgo the comforts of 'home' to build and sustain an outdoor community. Braving the elements, campers live outside for extended periods of time on cobblestone streets, muddy grasslands or up trees. A large part of the symbolic significance of protest camps comes from the visible disruptions they cause to normative visions of daily life and domestic space. The idea that someone would choose to live outdoors, often with strangers, invokes Final, accepted version. To be published in Sociological Review 
responses of bewilderment, intrigue, compassion and disgust (Feigenbaum 2008). For example, Cresswell (1996) argues that Greenham Common protest campers' performance of the rituals of daily life, from cooking and bathing to parenting and displaying affection, presented an "alternative aesthetics" to those of the surrounding geography (1996:124). Working with Cresswell's analysis, Nick Couldry writes that Greenham 'turned inside out' the 'regular patterns' separating domestic/non-domestic, public/non-public and mediated/non-mediated space (1999:345). In a more recent example, images of protesters sweeping the streets in Spain with donated brooms were heavily circulated in the media during the 'Real Democracy' campaign in May 2011. A crèche, library and vegetable garden set up at the Madrid encampment featured in numerous stories, creating a domestic scene. Thus the protest camp serves not only as a base for collective action and political convergence, but also as a space of home-building where the dynamic interrelation between campers' tasks can shift from tea making to non-violence training within minutes. While protest camps have been studied as 'places out of place' (Cresswell 1996) and in a more general sense as spaces that stand in a certain relationship to their outside, there is little knowledge with respect to the relational dynamics within the protest camp as a domestic space of day-to-day exchanges.

To summarize, this section has identified four key features of spatiality in protest camps. 'Contested spaces' refer to the ways in which camps are a form protest in themselves. Protest camps also function as markers of protest movements; both in Final, accepted version. To be published in Sociological Review 
the external and internal view, and as such function as 'representational spaces'. Protest camps thirdly provide a site for activists to come together or 'converge', sharing skills and ideas. The forum for exchange that the physical and imagined community of the protest camp creates can thus be thought of, following Routledge (2003), as a 'convergence space'. Fourthly, protest camps provide shelter, food, services and sanitation systems for protesters, serving as a 'home place' for protesters.

Affect

To analyse the relational dynamics of protest camps we have clustered the next section around theories of affect. We are interested in theories of affect that are concerned with the bodily sensations of daily life as they alter experience and interaction, moving us toward, as well as potentially alienating us from, each other (Gregg and Seigworth 2010). Approaching protest camps as sites of affect allows us to better account for the ways that sensations and feelings effect people's perspectives toward others, as well as towards objects and ideas. This helps us better understand how people come together (and fail to come together) in the space of the protest camp to imagine alternative worlds and enact transformational democracy.

Over the past few decades Social Movement research has increasingly addressed the roles that emotions and affect play in political processes. Concepts such as activist 'reframing' of emotions (Snow and Benford 1988, cited in Flam 2005:23) and the generation of 'feeling rules' (Hochschild 1982, cited in Flam 2005:24) provide insight into how social movement participants construct and transform Final, accepted version. To be published in Sociological Review 
emotional processes. Describing how these concepts function in the movement context, Helena Flam writes that 'self-defeating feelings' are suppressed and in their place 'new, assertive emotions' are proposed (2005:24). While broadening the traditional focus of social movement studies beyond resources and rational decision-making, this new scholarship on emotions tends to hold onto a reason/emotion dichotomy that subordinates 'feelings' to cognition (cf. Eyerman and Jamison 1998).

James Jasper offers a different perspective, arguing: 'Emotions do not merely accompany our deepest desires and satisfactions; they constitute them, permeating our ideas, identities, and interests. They are ... the 'glue' of solidarityand what mobilizes conflict' (Jasper 1998:399). 'Yet researchers', Jasper claims, 'trot out emotions only to study Nazis, moral panics, and other movements they dislike' (ibid 420-421). Jasper argues that social scientists, particularly those that are sympathetic to social justice causes, veer away from the emotional dynamics of radical politics as they 'assume that their rationality is somehow at stake' (ibid 429-421). Perhaps evidencing this, there are far more studies on emotion in religious fundamentalist networks than any other groups.

Working with another population that is often dismissed as irrational, Lawrence Grossberg introduces his notion of affect in studies of rock music fans. He develops the concept of 'mattering maps' that are formed from our affective alliances toward particular activities, practices and identities (1992:59). Interestingly, this relatively early conception of 'affect' drawn largely from Raymond Williams (1977) work on the 'Structure of Feelings' is less often taken up Final, accepted version. To be published in Sociological Review 
by theorists grouped together under the more recent 'Affective Turn' (Clough and Halley 2007, Gregg and Seigworth 2010). This scholarship tends to follow Brian Massumi's distinction between affect and emotion. Massumi argues that affect is pre-discursive or pre-linguistic, whereas emotions are interpreted through existing (normative) cultural lenses.

In the study of protest camps we take an approach which recognizes affect as bodily sensation. At the same time we acknowledge the difficulty-especially in writing—of separating out emotion from affect. Thus, we employ a loose definition that parallels Turid Markussen's use of the term affect. She explains, 'When I talk of affect or feeling I mean not just the emotions, but also the less easily categorizable ways in which we, in embodied ways, interact perceptively with that which is beyond us' (2006: 293).

From this understanding, we look empirically at how affect is bound up in the everyday actions and encounters of people living and working at protest camps. Here we see affect as linked to bodily transformations, or what we have elsewhere called 'transformative encounters (Feigenbaum, McCurdy and Frenzel 2013). As Munro and Belova write, affect 'seems to alter the very fabrication of the world' (Munro and Belova 2009: 96). In the space of the protest camp these alterations arise from the experiences and encounters of living and working together. As protest camp participants are often in contact with one another for hours at a time (whether cooking, blockading or fetching water), a variety of encounters take place in a single day. These everyday experiences bring about sensations that generate our potential to act in new ways (Feigenbaum, McCurdy Final, accepted version. To be published in Sociological Review 
and Frenzel 2013). John Jordan describes engaging in direct action as an 'inherent rush' in which the 'excitement and danger of the action creates a magically focused moment, a peak experience, where the real time suddenly stands still and a certain shift in consciousness can occur" (Jordan 1998, p. 133).

Sara Ahmed's theorisation of emotion in political communities is particularly useful to a study of affect in protest camps. For Ahmed, affect is what bind subjects together. As affect travels it accumulates value, moving sideways to create attachments, moving backwards to connect us to the past $(2003$, p. 120). Ahmed argues that collective formations emerge out dialogical practices, 'the conversations, the doing, the work' (2004, p. 188). In the case of protest camps, a number of significant differences arise between and among protesters as they engage in the daily work that constitutes life at the camp. The asymmetry of individuals' encounters and experiences of protest camp life generates what Ahmed (1998:67) has elsewhere termed 'the differences that matter'.

To summarize the cluster of affect, we argue that protest camps cannot be understood through dichotomous readings of rationality and emotions. Protest camps, in their role as a 'convergence space' in which diverse people and ideas come together, function as sites of transformative encounters in which affect moves us toward and away from each other. Affect is central in producing both the conflicts and affinities that shape collective and individual identities at protest camps. By politicising the embodied, everyday practices involved in sustaining the protest camps as a home space, campers are able to connect the politics of daily life to the project of building community and political alternatives. 
Autonomy

Protest camps are formative to participants' political identities, and they also shape and form social movements and other collective identities. In this respect protest camps relate to the history of the leisure camp and its foundation in the context of youth movements in the late 19th century in the United States, Britain and Germany (Smith 2006; Hetherington 1998). Organised camping was invented parallel in the German Wandervögel movement, the American summer camps and the British boy scouting in the last decades of the 19th century (Hailey 2009). Since their historical foundation, organised camps have diversified and they are used across cultural and political boundaries today. In his cartography of camps, Hailey (2009) has grouped protest camps together with leisure camps under the category of autonomy, indicating that much of the character of modern camping, even in its un-political tourist variety, plays with the notion of autonomy. Historically camps like boy scouts or summer camps instrumentalized the idea of autonomy for an educational function of the camp. In this sense, the hands-on experience of out-door-living and DIY were considered central to the development of young people (Smith 2006). The playfulness of autonomy that is practiced in tourist camping has evoked some to consider an inherent political meaning or allegory of leisure camping even if campers themselves don't intent their camping to be political in any way. Cohen (2009) argues for the political nature of camping as all camping activity provokes questions of how to organise collective life. He also posits that the study of leisure camping shows humans voluntarily engaged in Final, accepted version. To be published in Sociological Review 
mutuality and solidarity. He argues that therefore leisure camping prefigures an alternative to the political status quo of capitalism. Hailey (2009) differentiates the expression of autonomy in camps by proposing two modes. Autonomy is established either through pre-formulated rules that govern camp life or by a shared antagonism towards the outside of the camp.

Pre-formulated rules that govern camp life are an important feature in the history of leisure camping. They express autonomy, according to Hailey (2009) because they mark the difference of the governance and organisation of camp life internally to the outside. Like a clear antagonism, these mark the exceptionality of the camp (Frenzel 2013). Important questions arise in regards of the nature of the exception and its political function. Considering Agamben's (1998) notion of the camp as a space of exception, exceptionality should not be seen as necessarily progressive or antagonistic to the status quo. Even in voluntary, leisured camping, one must ask to what extent the exceptional space of the camp serves as an integrated exception. Despite their tangible exceptionally, the camps might be integral to the 'status quo' and not aimed or successful at challenging it.

Autonomy in protest camps is often established through an antagonism, aiming at creating an exceptional space that explicitly stands against the surrounding status quo. The camp comes into place because people desire to organize life in different ways to the surrounding world.

Summarizing a breadth of social movement literature on the notion of autonomy, Böhm et al. (2010) identify the search for autonomy across social movements in three different terrains. They argue that social movements seek autonomy from Final, accepted version. To be published in Sociological Review 
capital, from the state and from global institutions like the World Bank and the International Monetary Fund. This drive for 'autonomy from' is mirrored by an urge of 'autonomy to', aiming at the creation of autonomous forms of social organization. Reflections and analysis of 'new social movements' has recognised that protest movements since the 1970 s have increasingly rejected existing organizational frameworks of collective mass action where unity overrides diversity (Crossley 2003). The notion of the 'movement of movements,' coined to describe the global justice movement summarizes this focus on diversity. In protest camps we often see that modes of action follow the principle of a 'diversity of tactics' through an action set up that favours autonomous political action by small affinity groups. Rather than agreeing an overall strategy for political action, the plurality of affinity groups, at times in combination with a broad 'action consensus' (e.g. nonviolence), leaves the decision over which action to take and how far to go with the groups. This applies similarly in the context of representation. Protest camps often defy the notion of representational politics. Protest camps tend not to formulate shared demands or aggregate them to coherent political ideologies. This nonrepresentational drive is central to protest camps and also forms one of its key challenges.

The discussion of autonomy in the camp evokes the notion of bio-politics (Hardt and Negri 2009). We see in this term a critical qualification of debates that have framed social movement activism in 'late modernity' as increasingly concerned with questions of the 'grammar of life' (Crossley 2003, Habermas 1984) and personal or life-politics (Giddens 1991). In this vein 'new' social movement 
research sometimes separates the search for autonomy from classical work-placebased social movement politics. Bio-politics - on the contrary - points to the importance of the combination of the search for autonomy with notions of care and solidarity as exemplified in struggles over the role and valorisation of reproductive labour (Federici 2004).

Protest camps have played important roles and tools of aggregation and organisation in these developments. We argue that protest camps partly result from the desire for autonomy and for organizational forms that enable autonomy. In protest camps autonomy can be put into organizational practice and collectively lived. Other than in institutional set ups, autonomy is not a question simply of ideology or identity, but it's becoming tangible as experience. In this light it is illuminating to take a look at the M11 protest camps, on which McKay (1996) concluded:

Compared to even a traditional labourist struggle, such as the signal workers' dispute which occurred at the same time as the M11 campaign was at its height, the amount of money the [M11] campaign cost the government is actually small potatoes. Therefore the key to the political significance of the No M11 campaign lies less in the immediate costs incurred by capital and the state (although these are great achievements and great encouragement to others), and more in our creation of a climate of autonomy, disobedience and resistance (McKay 1996: 106-107).

In summary, protest camps can be studied as tangible manifestations of an increasing drive for politics that are in a broad sense concerned with autonomy. Firstly protest camps seem to align well with drives for 'non-representational politics'. This concerns both their actions and their communications, where small affinity groups retain the prioritised form. Moreover protest camps enable 


\section{Protest Camps}

participants to put into practice notions of 'bio-politics', where the political act of the movement is not exhausted in formulating demands but extends to the proliferation of new social forms of being. This all points to protest camps as embodied exceptionality for they enable the lived experience of autonomy. For the study of protest camps two main challenges arise here. Firstly the link between autonomy and protest camps needs to be critically assessed. Current writing on protest camps puts them largely in the context of Western 'new social movements' and alter-globalisation protest, a view that now appears insufficient. To what extent has the global occurrence of protest camps shifted the meaning of autonomy? Is it, for example, enough to read them in the anti-institutional, anticapital and anti-development triad that Böhm at al (2010) had formulated? Do protest camps always express a desire for autonomy? In reading protest camps across the social and cultural boundaries in which they have been studied so far, their comparative analysis might provide an approach to better understand current pro-democracy movements and their organisational forms. Secondly, by being set against the status quo, the camps' claim to autonomy is often questionable. Don't protest camps continue to exist within the legal and political status quo of the surrounding polity? Are they - despite the antagonism that constitutes them - only playing with autonomy rather than having it? The study of autonomy as expressed in the camp, would benefit from closer reflection on how autonomy is made and becomes tangible in camps.

An infrastructural analysis of protest camps 
In the previous part of the paper we situated existing protest camp research into the three conceptual clusters of spatiality, affect and autonomy. Identifying literature that indicated the importance of these clusters for the better understanding of protest camps, we showed the limits of existing research and the lack to address protest camps as unique political and organisational forms. In particular we highlighted the importance of being able to compare protest camps across a variety of contexts. To enable such comparisons, we derived four central features from the discussion of each of the clusters. These concepts can be understood as heuristic devises for the analysis of the tangible ways in which protest camps work. We therefore propose to examine 1) the way protest camps use, contest and transform space; 2) how they interact with each other beyond dichotomies of private and public, rational and emotional, conflict and cooperation, and belonging and difference; and 3) how they seek autonomy in pursuing biopolitical, non-representational and diverse strategies to render protest camps exceptional to the surrounding status quo. (Insert Table 1 here)

\begin{tabular}{|l|l|l|l|l|}
\hline Spatiality & $\begin{array}{l}\text { Home } \\
\text { Spaces }\end{array}$ & $\begin{array}{l}\text { Contested } \\
\text { Spaces }\end{array}$ & $\begin{array}{l}\text { Representational } \\
\text { Space }\end{array}$ & $\begin{array}{l}\text { Convergence } \\
\text { Space }\end{array}$ \\
\hline Affect & Affective & Conflict and & Transmissions of \\
attachments & collaboration & affect & $\begin{array}{l}\text { Belonging and } \\
\text { difference }\end{array}$ \\
\hline Autonomy & Bio-Politics & Affinity & Non- & Exceptionality \\
\hline
\end{tabular}


\begin{tabular}{|l|l|l|l|l|}
\hline & & & Representation & \\
\end{tabular}

Table 1: Clusters for the study of protest camps

While these concepts offer tools for analysing protest camps, we needed to find a way to operationalise them for the analysis of empirical cases. As campers endeavour to create localised centres for protest, they often build operational structures including DIY sanitation systems, communal kitchens, crèches, vegetable gardens, media centres, libraries, cultural festivals, and performances, as well as childcare, legal and medical services. As indicated earlier this relates to a long history of DIY approaches to learning and education, and to the broader task of building alternative worlds.

Protest camps require engagements between campers and technologies in the broadest sense. Many technology theorists have made the argument that 'technology' does not refer only to self-contained technical objects, but also to the social, economic and cultural systems which physically construct and give meaning to what we think of as 'technologies' (Cowan 1985). Actor-Network Theory (ANT) furthers this approach, as it examines the relations between individuals, groups and objects (Law and Hassard, 1999; Latour, 2005). As it is concerned with relations between individuals, groups and objects, this approach is useful for analyses of sites that address power and its potential transformation. Actor-Network Theory--particularly in its updated versions--provides a method for thinking about how interdependencies between people, groups and objects 
emerge and function in relation to each other. It is particularly useful for thinking about how human and non-human agents are always enmeshed. Thierry Bardini offers this illustrative summary:

[Actor-Network Theory] describes the progressive constitution of a network in which both human and non-human actors assume identities according to prevailing strategies of interaction. Actors' identities and qualities are defined during negotiations between representatives of human and nonhuman actants... The most important of these negotiations is "translation", a multifaceted interaction in which actors (1) construct common definitions and meanings, (2) define representatives, and (3) co-opt each other in the pursuit of individual and collective objectives (Bardini, 1997: $\mathrm{ft}$ 3).

Employing this notion of 'translation', the process of joining together to maintain and operate a protest camp can be read as a series of engagements in which human actors (campers, supports, locals, government officials) and non-human objects (tents, tools, kitchen equipment, communication technologies, toilets) enter into particular relations with each other. Each human actor might have different orientations to camp life (experienced campaigner, first time camper, weekend visitor, looking for shelter) and varying motivations for taking part in it, but through their operation of the tasks needed to achieve a common goal they negotiate (or fail to negotiate) a way to function together, manifesting a 'protest camp'.

The negotiations involved in working together and negotiating the creation and sustainable operation of the protest camp are often emotionally loaded or 'buzzing with affect'. This affective intensity arises out of the different experiences and political orientations of protest campers (Feigenbaum 2008, Feigenbaum, McCurdy, Frenzel 2013). ANT is sometimes criticised for failing to explicitly 
account for how power relations shape interactions (cf McClean and Hassard 2004), but those working with what is sometimes called 'ANT and After' (Law and Hassard 1999) or 'post-ANT' (Gad and Jensen 2010), argue instead that ANT literature can make explicit the ways in which power and difference are performed and played out--i.e. gender, race, and class, as well as the many everyday associations and disassociations we make to one another (Alcadipani and Hassard, 2010). Moreover, ANT approaches are concerned with, as Alcadipani and Hassard (2010) put it, "how realities are enacted into being and different entities can be constructed; they highlight that things could be 'otherwise' and that realities are not 'destiny' (Law, 2007)" (Alcadipani and Hassard 2010, 427). ANT critics also sometimes accuse the approach to have a tendency to obscure agency and intention (cf McClean and Hassard 2004), however we engage with ANT to not to reject human decision-making, but rather, as Karen Barad argues, to rethink protest camps as entanglements of humans and nonhumans and to treat objects and infrastructures as more than "passive and inert" (Barad, 2007, pp. 245-246). This allows us to study protest camps comparatively across time and place, enables us to trace shared functions of camps beyond specific political trajectories and intentionalities. These more contextual aspects, however, remain equally central to the understanding of protest camps.

The different interdependent operational functions that make up the protest camp can be clearly categorised and distinguished as infrastructures. By common definition, infrastructures refer to the organised services and facilities necessary for supporting a society or community. We therefore use the term 'infrastructure' Final, accepted version. To be published in Sociological Review 
in its basic meaning to capture how camps build interrelated, operational structures for daily living. These structures function together to disseminate information, distribute goods and provide services. In order to conduct our analysis and work to code the recurring sets of structured objects, practices, and behaviours that make up protest camps, we have identified four key infrastructures. (Insert Table 2 here)

\begin{tabular}{|l|l|l|l|l|}
\hline Spatiality & Home & $\begin{array}{l}\text { Contested } \\
\text { Spaces }\end{array}$ & $\begin{array}{l}\text { Representational } \\
\text { Space }\end{array}$ & $\begin{array}{l}\text { Convergence } \\
\text { Space }\end{array}$ \\
\hline Affect & Affective & $\begin{array}{l}\text { Conflict and } \\
\text { attachments }\end{array}$ & $\begin{array}{l}\text { Transmissions of } \\
\text { affect }\end{array}$ & $\begin{array}{l}\text { Belonging } \\
\text { and difference }\end{array}$ \\
\hline Autonomy & Bio-Politics & Affinity & Non & Exceptionality \\
& $\downarrow$ & representation & \\
\hline & $\begin{array}{l}\downarrow \\
\text { Infrastructures }\end{array}$ & Domestic & Action & Communication \\
Infrastructure & Infrastructures & Infrastructures & Governance \\
& & & Infrastructures \\
\hline
\end{tabular}

Table 2: Matrix for the analysis of protest camps.

Derived from our previous empirical studies on Greenham Common (Feigenbaum 2008, 2010, 2012), the 2005 G8 Counter Summit's HoriZone Eco Camp (McCurdy 2008, 2009, 2010, 2011a, 2011b; Frenzel 2010), Climate Camps (Frenzel 2013, Final, accepted version. To be published in Sociological Review 
2011, 2010; Feigenbaum 2007), and the G8 camps in Germany 2007 (Frenzel 2010), as well as ongoing research (Feigenbaum, Frenzel and McCurdy 2013), these four infrastructures appear generalisable to most protest camps.

We use these infrastructures and their relationship to the thematic clusters developed earlier to create a matrix that enables the comparative analysis of protest camps. The four key infrastructures we have identified are: (1) domestic infrastructures (food supply, shelter, sanitation, maintenance of communal and private space); (2) action infrastructures (direct action tactics, education, police negotiations, legal aid, medical support, transportation networks); (3) communication infrastructures (media strategies, distribution networks, production techniques); and (4) governance infrastructures (formal and informal decisionmaking processes, rules and procedures). As these organisational dimensions dynamically interact, they enable and hinder each other, creating specifically configured protest camps. By looking at the organisational form of the protest camp, we investigate the historical learning processes and (dis-) continuities between social and cultural movements across the world that use protest camping as part of their political mobilisations.

\section{Conclusion}

Recent global events have shown the growing importance of protest camps as an organisational form of protest. Despite their prevalence in contentious politics over the last 30 years, they have not been systematically and comparatively studied. In this paper, we propose to pursue the study of contemporary and historic protest Final, accepted version. To be published in Sociological Review 
camps as a field of research in social movement studies. We discuss and develop an infrastructural analysis to enable the study protest camps beyond the political, social and temporal contexts in which they stand. This might provide inroads to explain better why protest camps are such a popular form of protest today, and why they seem to transcend cultural and political boundaries, being used by movements across the world.

We set out to review existing literature on protest camp and arranged this literature into three thematic clusters. In respect of spatiality we found that while protest camps are symbolic spaces and often function as representational space, they draw their power from being in particular physical locations and from having particular infrastructural features. Concerning affect, protest camps have been theorised as places in which daily interaction shape emotions, actions and ideas and allow for close proximity of protesters and affective bonds between them. Protest camps provide a 'home' space, paradoxically often by claiming very inhospitable spaces. In respect to autonomy it has become clear that protest camps are spaces in which activists form individual and collective identities outside of institutionalized groups and organisations and the status quo. Protest camps' unique autonomous forms of organization sustain the promise and the possibility to start a-new and to fundamentally renew and reshape the polity in what has been described as bio-politics. The debates grouped in all three clusters have highlighted the centrality of materiality to the study of protest camps. This leads us to propose to study protest camps through the lens of their infrastructures. A 'hands-on' and 'DIY' approach is central to how protest campers Final, accepted version. To be published in Sociological Review 
approach politics and is also - we contest - the best way of researching protest camps. Drawing from the discussion of the thematic clusters, we developed a matrix in which the thematic clusters are set in relation to proliferating infrastructures, shared between camps and key features to enable them. We termed the four infrastructures 'domestic', 'action', 'communication' and 'governance'. Treating these areas as threads, they can be used to tie together diverse sets of protest camps.

On the basis of our own empirical research on protest camps and the emerging evidence from protest camps across the world, protest camps seem not simply a passing or accidental tactics of specific movements at specific times. Rather protest camps seem to respond to the desires of protesters to move beyond 'demands' and towards a constituent politics of claiming space, building affective ties and forming autonomous polities. And even if such radical approaches are not shared by all participants, we argue that protest camps have the potential to enable an experience of new and alternative forms of democracy for participants. Showing how protest camps configure their infrastructures to enable the experiences of participation, collaboration, collectivity and mutuality, we hope to contribute to the understanding of alternative forms of governance and political participation. More research is needed to examine whether such claims can be upheld or whether they must be relativised. Our own empirical studies have largely focused on Western camps and while we believe that the infrastructural analysis will enable us to compare non-Western camps, the results of such comparison might and probably will necessitate a re-thinking of what protest camps are. The Final, accepted version. To be published in Sociological Review 


\section{Protest Camps}

infrastructural analyses we developed is not meant to be a conclusive or prescriptive approach to the study of protest camps, but may hopefully serve as an orientation and starting point in a rich field where thus far there is dearth of analysis. With this paper, we have aimed to open a debate and discussion on protest camps, and to attract and encourage more research on protest camps.

\section{References}

Agamben, G., (1998), Homo sacer sovereign power and bare life. Stanford, Calif.: Stanford University Press.

Ahmed, S., (1998), Differences that matter: feminist theory and postmodernism. Cambridge UK; New York: Cambridge University Press.

--- (2004), The cultural politics of emotion. New York: Routledge.

Alcadipani, R., \& Hassard, J. (2010), 'Actor-Network Theory, organizations and critique: towards a politics of organizing.' Organization, 17(4), 419-435.

Barad, K., (2007). Meeting the Universe Halfway: Quantum Physics and the Entanglement of Matter and Meaning. Durham: Duke University Press. 
Protest Camps

Bardini, T. (1997), 'Bridging the Gulfs: From Hypertext to Cyberspace' Journal of Computer Mediated Communications, 3(2): 0-0.

Bey, H., (2003), T.A.Z.: the temporary autonomous zone, ontological anarchy, poetic terrorism. Brooklyn, NY: Autonomedia.

Böhm, S., Sullivan, S., Reyes, O., eds, (2005), 'The Organisation and Politics of Social Forums' ephemera: theory \& politics in organization 5(2) 1-25.

Böhm, Steffen, Ana C. Dinerstein, and André Spicer, (2010) '(Im)possibilities of Autonomy: Social Movements in and beyond Capital, the State and Development.' Social Movement Studies: Journal of Social, Cultural and Political Protest 9(1):1735

Brennan, T. (2004), Transmission of Affect. Ithaca: Cornell University Press.

Brown, S.L. (2002) Intentional Community: An Anthropological Perspective, New York City: SUNY Press.

Chesters, Graeme, and Ian Welsh, (2008), Social movements: the key concepts. London: Routledge.

-- 2004, 'Rebel colours: framing in global social movements' The Sociological Review 52(3): 314-335 
Protest Camps

Climate Camps, (2011), The camp for climate action webpage, available at http://climatecamp.org.uk/climate-camp-one-year-on

Clough, Patricia Ticiento and Jean O'Malley Halley, (2007), The Affective Turn: Theorizing the Social. Durham: Duke University Press.

Cohen, G. A., (2009), Why Not Socialism? Princeton University Press.

Couldry, Nick, (1999), 'Disrupting the media frame at Greenham Common: a new chapter in the history of mediations?' Media, Culture \& Society 21(3):337-358.

Cowan, Ruth, (1983), More Work For Mother: the Ironies of Household Technology from the Open Hearth to the Microwave. New York: Basic Books

Cresswell, Tim, (1996), In place out of place: geography, ideology, and transgression. Minneapolis: University of Minnesota Press.

Crossley, Nick (2003), 'Even Newer Social Movements? Anti-Corporate Protests, Capitalist Crises and the Remoralization of Society.' Organization 10(2):287-305. -- 2008, 'Social networks and student activism: on the politicising effect of campus connections' The Sociological Review 56(1): 18-38

Dark Star Collective, eds., (2002), Quiet Rumours: an anarcha-feminist reader. Edinburgh and San Francisco: AK Press.

Final, accepted version. To be published in Sociological Review

Page 30 of 40 


\section{Protest Camps}

Epstein, Barbara, (2002), 'The Politics of Prefigurative Community." in Cultural resistance reader, Duncombe, S. (ed). London New York: Verso: 333-346.

Escobar, Arturo, (2004), 'Beyond the Third World: imperial globality, global coloniality and anti-globalisation social movements.' Third World Quarterly 25(1):207-230.

Eyerman, Ron, and Andrew Jamison, (1998), Music and social movements: mobilizing traditions in the twentieth century. Cambridge [England]; New York: Cambridge University Press.

Federici, Silvia. (2004). Caliban and the Witch. Women, the Body and Primitive Accumulation. Brooklyn (NY): Autonomedia.

Feigenbaum, Anna, (2012), "Written in the Mud: Autonomous Media at the Greenham Common Women's Peace Camp," Feminist Media Studies, 12:02: TBD.

-- (2010), “'Now l'm a Happy Dyke!': Creating Collective Identity and Queer Community in Greenham Women's Songs," Journal of Popular Music, 22:4: 367388. 
Protest Camps

-- (2008), Tactics and Technology: Creative Resistance at the Greenham Common Women's Peace Camp. PhD Thesis, Montreal: McGill University.

-- (2007), "Death of a Dichotomy: Tactical Diversity and the Politics of PostViolence. A Review of Ward Churchill (AK Press 2007) Pacifism as Pathology and Peter Gelderloos (South End Press 2007) How Nonviolence Protects the State" in Upping the Anti, 1:5 available at http://uppingtheanti.org/iournal/article/05-death-of-adichotomy.

Feigenbaum, Anna, Fabian Frenzel \& Patrick McCurdy (forthcoming). Protest Camps: Imagining Alternative Worlds. Zed (in process for publication by Autumn 2013).

Feigenbaum, Anna, Patrick McCurdy and Fabian Frenzel (2013) "The Campfire Chats Project: Exploring The Objects and Affects of Everyday Life at Occupy Protest Camps," Parallax 19/2 21-32

Flam, Helena, (2005), Emotion's map: A research agenda. in Helena Flam and Debra King (eds) Emotions and social movements. London New York: Routledge: $19-40$. 
Frenzel, F. (2013) The Politics of Mobility: Some insights from the study of Protest Camps. In S. Kesselring \& G. Vogl, eds. New Mobilities Regimes: The analytical power of social sciences and the arts. London: Ashgate, p. forthcoming.

---- (2011) Entlegende Ort in der Mitte der Gesellschaft Die Geschichte der britischen Klimacamps [in German]. In A. Brunnengräber, ed. Zivilisierung des Klimaregimes: NGOs und soziale Bewegungen in der nationalen, europäischen und internationalen Klimapolitik. Wiesbaden: VS Verlag für Sozialwissenschaften, pp. 163-186.

--- (2010) Politics in Motion. The Mobilities of Political Tourists. PhD Thesis. Leeds Metropolitan University.

Gad, C., \& Bruun Jensen, C. (2009). 'On the Consequences of Post-ANT. Science, Technology \& Human Values,' 35(1), 55-80.

Giddens, A (1991) Modernity and self-identity: self and society in the late modern age, Stanford University Press.

Greenwood, D. and Levin, M, (2007), Introduction to Action Research. London: Sage.

Gregg, Melissa and Greg Seigworth, (2010), The Affect Theory Reader. Durham: Duke University Press. 


\section{Protest Camps}

Grossberg, Lawerence, (1992), 'Is There A Fan In the House?: The Affective Sensibility of Fandom.' Lisa Lewis (ed) The Adoring audience: fan culture and popular media. London New York: Routledge: 50-65.

Habermas, J. (1984) The theory of communicative action, Boston: Beacon Press.

Hailey, Charlie, (2009), Camps: a guide to 21st-century space. Cambridge Mass.: MIT Press.

Hardt, Michael, and Antonio Negri, (2009), Commonwealth. Cambridge Mass.: Belknap Press of Harvard University Press.

-- (2004), Multitude: war and democracy in the age of Empire. New York: The Penguin Press.

-- (2000). Empire. Cambridge Mass.: Harvard University Press.

Halsey, M. and Young, A, (2006), 'Our desires are ungovernable: Writing graffiti in urban space.' Theoretical Criminology, 10(3): 275-306.

Hetherington, Kevin, (1998), Expressions of identity: space, performance, politics. London:Thousand Oaks Calif.: Sage Publications.

Hodkinson, Stuart and Paul Chatterton (2007) 'Autonomy in the city? Reflections on the social centres movement in the UK' City - analysis of urban trends, culture, theory, policy, action 10(3): 305-315

Final, accepted version. To be published in Sociological Review 
Holloway, John, (2002), Change the world without taking power: the meaning of revolution today. London: Pluto.

Hooks, Bell, (1990), Yearning: race, gender, and cultural politics. Boston MA: South End Press.

Gamson, William A. and Gadi Wolfsfeld 1993 "Movements and media as interacting systems." Annals of the Ammerican Academy of Political and Social Science 526, pp. 114-27

Jasper, James, (1998) 'The Emotions of Protest: Affective and Reactive Emotions in and around Social Movements.' Sociological Forum 13(3):397-413.

John J. (1998) 'The Art of Necessity', in DiY Culture: Party \& Protest in Nineties Britain, ed. George McKay. London and New York: Verso.

Juris, Jeffrey, (2008), Networking futures: the movements against corporate globalization. Durham N.C.: Duke University Press.

Keraghel, C., and J. Sen, (2004), 'Explorations in open space. The World Social Forum and cultures of politics.' International Social Science Journal 56(182):483493. 


\section{Protest Camps}

Laraña, Enrique, Hank Johnston, and Joseph R Gusfield, (eds), (1994), New social movements: from ideology to identity. Philadelphia: Temple University Press.

Latour, Bruno, (2005), Reassembling the social. Oxford: Oxford University Press.

Law, J. and J. Hassard, (1999), Actor network theory and after. New York: Wiley and Blackwell.

Law, J (2007) Actor Network Theory and Material Semiotics available at http://www.heterogeneities.net/publications/Law2007ANTandMaterialSemiotics.pdf

Leontidou, L. (2007) 'Urban social movements: from the "right to the city" to transnational spatialities and flaneur activists'. City - analysis of urban trends, culture, theory, policy, action 10(3): pp.259-268.

Massumi, Brain, (2002), Parables for the Virtual: movement, affect, sensation.

Durham: Duke University Press.

Markussen, T, (2006) 'Moving worlds: The performativity of affective engagement' Feminist Theory December 7: 291-308 
McCurdy, Patrick, (2008), Inside the media event: Examining the media practices of Dissent! at the Hori-Zone eco-village at the 2005 G8 Gleneagles Summit. Communications - European Journal of Communication Research 33: 293-311.

-- (2009), 'I Predict a Riot' - Mediation and Political Contention: Dissent!'s media practices at the 2005 Gleneagles G8Summit.' PhD Thesis, London: London School of Economics [available at http://etheses.Ise.ac.uk/5/] Retrieved December 10, 2011.

-- (2010), Breaking the spiral of silence - Unpacking the 'media debate' within Global Justice Movements: A Case Study of Dissent! and the 2005 Gleneagles G8 Summit, Interface: A journal for and about social movements 2: 42-67.

-- (2011a), The Fragility of Dissent!: Mediated Resistance at the Gleneagles G8 Summit and the Impact of the 7/7 London Bombings, Culture, Language and Representation 9: 99-116.

-- (2011b), Theorizing Activists' 'Lay theories of media': A case study of the Dissent! Network at the 2005 G8 Summit, International Journal of Communication 5: $619-638$

McKay, George, (1998), DiY culture: party \& protest in Nineties Britain. London; New York: Verso. 
Protest Camps

-- (1996), Senseless acts of beauty: culture of resistance since the sixties.

London; New York: Verso.

McLean, C. and Hassard, J. (2004) 'Symmetrical Absence/Symmetrical Absurdity:

Critical Notes on the Production of Actor-Network Accounts', Journal of

Management Studies 41(3): 493-519.

Montagna, Nicola (2007) The de-commodification of urban spaces and the occupied social centres in Italy City - analysis of urban trends, culture, theory, policy, action 10(3): 295-304

Montagna, N, (2010) 'The making of a global movement: Cycles of protest and scales of action' The Sociological Review 58(4): 638-655

Munro, R and Belova, O (2009) The body in time: knowing bodies and the 'interruption' of narrative' The Sociological Review 56(S2): 85-99

Nunes, Rodrigo, (2005), 'The Intercontinental Youth Camp as the Unthought of the World Social Forum.' ephemera: theory \& politics in organization 5(2): 277-296.

Offe, C, (1987), 'Challenging the boundaries of institutional politics: social movements since the 1960s.' Charles Maier (ed) Changing boundaries of the political: essays on the evolving balance between the state and society, public and Final, accepted version. To be published in Sociological Review 
private in Europe. Cambridge [Cambridgeshire]; New York: Cambridge University Press: 63-105.

Patomaki, H., and T. Teivainen, (2004) 'The World Social Forum: An Open Space or a Movement of Movements?' Theory, Culture and Society 21:145-154.

Pickerill, Jenny, and Paul Chatterton, (2006), 'Notes towards autonomous geographies: creation, resistance and self-management as survival tactics.' Progress in Human Geography 30(6):730-746.

Routledge, Paul, (2000), "'Our resistance will be as transnational as capital": Convergence space and strategy in globalising resistance.' GeoJournal 52(1):2533.

-- (2003), 'Convergence space: process geographies of grassroots globalization networks.' Transactions of the Institute of British Geographers 28(3):333-349.

Santos, Boaventura de Sousa, (2004), 'The World Social Forum: Towards A Counter-Hegemonic Globalisation (Part I).' Jai Sen, Anita Anand, Arturo Escobar, and Peter Waterman (eds), World Social Forum: challenging empires. New Delhi: Viveka Foundation: 235-245

Schehr, R.C. (1997). Dynamic Utopia: Establishing Intentional Communities As a New Social Movement, Greenwood Publishing Group. 


\section{Protest Camps}

Scott, Alan, (1990), Ideology and the new social movements. London; Boston: Unwin Hyman.

Smith, M. B., (2006). "The Ego Ideal of the Good Camper" and the Nature of Summer Camp.' Environmental history 11(1):70-101.

The Free Association, (2010), 'Antagonism, Neo-liberalism and Movements: Six Impossible Things Before Breakfast.' Antipode 42(4): 1019-1033.

Wallerstein, Immanuel Maurice, (2004), 'The dilemmas of open space: the future of the WSF.' International Social Science Journal 56(182): 629-637.

Williams, Raymond, (1977), Marxism and Literature. Oxford: Oxford University Press. 